\title{
ALINA RYNIO, IDEA NARODU I ODPOWIEDZIALNOŚCI ZA NARÓD W KAZANIACH MILENIJNYCH CZCIGODNEGO SEUGI BOŻEGO KARDYNALA STEFANA WYSZYŃSKIEGO. STUDIUM HOMILETYCZNO-PEDAGOGICZNE, LUBLIN 2020, SS. 153, ISBN 978-83-8061-6206
}

Kardynał Stefan Wyszyński to postać wielowymiarowa, a jego spuścizna i dziedzictwo są tak znaczące, iż wciąż mają wpływ na nas, współczesnych. Nieustająco też domagają się odkrywania na nowo, upowszechniania oraz interpretowania w kontekście aktualnych zjawisk i procesów zachodzących w Kościele, narodzie i państwie.

Skąd jednak pochodzi społeczne przeświadczenie o dziejowej roli S. Wyszyńskiego oraz źródło jego autorytetu? Wydaje się, iż wiąże się ono z powszechnym uznaniem go za męża stanu, co można postrzegać nawet jako pewien proces mitologizacji. Ksiądz prof. Zygmunt Zieliński uzasadniał, iż S. Wyszyński był mężem stanu zarówno na polu kościelnym, jak i państwowym. Na pierwszym przejawiało się to poprzez konieczność podejmowania samodzielnych decyzji, wymuszaną przez komunistyczną rzeczywistość. Z kolei w życiu publicznym stawał się nim:

ilekroć we znaki dawał się brak wiarygodnego autorytetu, któremu naród mógłby w pełni zawierzyć. Wydarzenia z lat 1956, 1970, 1976, 1980-1989 dowiodły, że autorytety, nawet jeśli się pojawiały, szybko się dewaluowały. Pozostał jeden, a był nim człowiek, słusznie chyba, choć może dla ucha nieco pompatycznie, nazwany Prymasem Tysiąclecia ${ }^{1}$.

Zatem kluczem do zrozumienia fenomenu osoby i dzieła S. Wyszyńskiego jest społeczna potrzeba autorytetu. Ważna jest też świadomość istoty wspomnianego autorytetu, tak aby uniknąć bezkrytycznej hagiografii. Zachodzący w przypadku postaci Prymasa proces przechodzenia $z$ etapu pamięci żywej w pamięć historyczną nie może postępować w kierunku narzuconej z góry wizji apologetycznej, lecz winien odbywać się poprzez analizę, przede wszystkim naukową, a następnie wskazanie

${ }^{1}$ Zygmunt Zieliński, Kościół w kręgu rzeczywistości politycznej (Lublin: Wydawnictwo KUL, 2003), 154. 
znaczenia tego autorytetu, zarówno w wymiarze osobistym - indywidualnym, jak i zbiorowym - powszechnym. Postępujące „przewartościowanie” dotychczasowego kanonu wartości będące skutkiem pogłębiającego się kryzysu kulturowego powoduje, iż szczególnie młodzi ludzie odrzucają zastane i ugruntowane społecznie autorytety. Zatem należy skoncentrować się na tym, aby ten wyjątkowy autorytet, jakim jest S. Wyszyński, nie został współcześnie przez Polaków zmarnowany i zdewaluowany. A wciąż spełnia on wobec naszego narodu następujące funkcje: przewodnika pomagającego odnaleźć drogę życiową, będącego źródłem oparcia i nadziei; integracyjną; selekcyjną, która polega na transmisji konkretnych wartości; inspirującą i wychowawczą; porządkującą (wzorcotwórczą) i stabilizującą - szczególnie ważnych w czasie zagrożeń oraz radykalnych przemian².

Kontekst czasu oczekiwania na beatyfikację Kardynała powinien być wykorzystany na pogłębioną refleksję naukową, mającą na celu kompleksową próbę zrozumienia, wyjaśnienia i upowszechnienia znaczenia jego osoby oraz dziedzictwa dla Kościoła, narodu i państwa polskiego. Taką próbą jest publikacja pt. Idea narodu i odpowiedzialności za naród w kazaniach milenijnych Czcigodnego Stugi Bożego Kardynała Stefana Wyszyńskiego. Studium homiletyczno-pedagogiczne, której Autorką jest dr hab. Alina Rynio z Katedry Pedagogiki Chrześcijańskiej i Biografistyki Pedagogicznej Instytutu Pedagogiki Katolickiego Uniwersytetu Lubelskiego Jana Pawła II.

Praca składa się ze wstępu, pięciu rozdziałów merytorycznych i zakończenia. We wstępie Autorka wskazała na miejsce pojęcia rzeczywistości narodu w kaznodziejstwie, zwłaszcza na gruncie polskim. Znamienne jest przywołanie w tym miejscu opinii międzywojennego teoretyka kaznodziejstwa, ks. Wacława Kosińskiego, który uważał, iż problematyka tworzenia wspólnoty narodowej oraz odpowiedzialność za ojczyznę to kwestie ważkie z punktu widzenia kaznodziejstwa, a jako najważniejszych polskich kaznodziejów narodowych wskazał: Piotra Skargę, Fabiana Birkowskiego, Jana Pawła Woronicza, Hieronima Kajsiewicza, abpa Józefa T. Teodorowicza i abpa Antoniego Szlagowskiego ${ }^{3}$. W tę właśnie tradycję kaznodziejstwa narodowego Autorka wpisała osobę S. Wyszyńskiego, wskazując jako zasadniczy przedmiot swoich badań jego kazania i przemówienia zawarte w dwóch źródłowych tomach Kazania i Przemówienia 1966 w odniesieniu do problemu sformułowanego w tytule pracy ${ }^{4}$. Autorka sumienne wyjaśniła także, dlaczego poszukiwanie problemu narodu zawęziła do tej części prymasowskiej spuścizny pisarsko-intelektualnej, mając przy tym pełną świadomość, iż była ona także obecna na innych polach jego

2 Zob. Bożena Tuziak, „Autorytet jako zjawisko społeczne. Wymiar lokalny”. Studia Socjologiczne 2 (2010): 73-74.

${ }^{3}$ Por. s. 10 recenzowanej publikacji.

${ }^{4}$ Mowa tutaj o autoryzowanych tekstach kazań i przemówień S. Wyszyńskiego zawartych w tomach: Szlak milenijny od Gniezna 14 IV 1966 do Łomży 7 VIII 1966, t. 1; Szlak milenijny od Opola 13 VIII 1966 do Białegostoku 20 XI 1966, t. 2, zlokalizowanych w Bibliotece Maryjnej Instytutu Prymasowskiego Stefana Kardynała Wyszyńskiego w Warszawie. Por. s. 14 recenzowanej publikacji. 
twórczości i różnorodnej działalności. Ponadto we wstępie A. Rynio zawarła uwagi dotyczące kontekstu historycznego związanego z tematem swojego opracowania, czyli wyjaśnienia istoty i charakteru uroczystości milenijnych z 1966 roku. Omówiła też najistotniejszą literaturę przedmiotu, ważną z perspektywy stanu badań nad biografią i działalnością pisarską Prymasa Tysiąclecia, oraz wyjaśniła przyjętą strukturę pracy.

Pierwszy merytoryczny rozdział publikacji poświęcony został charakterystyce kaznodziejstwa Kardynała. Alina Rynio uporządkowała zawarty w nim materiał opisowy i analityczny w trzy podrozdziały, $\mathrm{z}$ których pierwszy to szkic biograficzny duchownego, spełniający w tym aspekcie jedynie funkcję pomocniczą, a jego chronologia obejmuje okres życia Prymasa wyłącznie do obchodów milenijnych.

Drugim zagadnieniem, jakie starała się naświetlić Autorka w rozdziale pierwszym, jest charakterystyka posługi kaznodziejskiej S. Wyszyńskiego. Dokonała jej przede wszystkim na gruncie teologicznym, dowodząc, iż podstawy jego przepowiadania są w swej istocie chrystologiczne, mariologiczne $i$ antropologiczne. Właściwa dla niego była forma orędzia ze świadectwem jako momentem kulminacyjnym ${ }^{5}$. Ostatnim elementem tego rozdziału Autorka uczyniła krótkie omówienie podstawowych celów kaznodziejstwa S. Wyszyńskiego.

W kolejnym rozdziale merytorycznym następuje wyjaśnienie prymasowskiego rozumienia narodu i pedagogii narodowej. W tym kontekście pojawia się termin „teologia narodu”, powiązany z teologią chrztu narodu.

W centrum uwagi Kardynał stawiał rodzinę, ponieważ to właśnie rodziny przechodzą pośrednio w naród, który jest rodziną rodzin. W rozumieniu przepowiadającego naród posiada też własną godność, otrzymaną od Stwórcy, a w relacji do Kościoła jest wielkością doczesną, świecką i autonomiczną. Istnieje na płaszczyźnie stworzenia i wkracza w świat historii zbawienia. Pomimo iż jest strukturalną stałą, zmienia się i tworzy historię, jest swoją historią oraz pozostaje otwarty na wartości chrześcijańskie.

W części pierwszej niniejszego rozdziału (Naród kategorią teologiczną i eklezjalnq) Autorka omówiła podstawowe elementy teologii chrztu narodu. Analizując teksty kazań, zauważyła, że S. Wyszyński praktycznie w każdym z nich wracał do dziejowego powiązania Kościoła z narodem, nazywając ten pierwszy „wiecznym świadkiem milenijnych dziejów narodu"6. Prymas tłumaczył, iż Kościół poprzez włączenie narodu do wspólnoty Mistycznego Ciała Chrystusa dał mu fundamentalne wartości, za które uznał: „życie, świętość, prawdę, krzyż i Ewangelię, Mszę św., błogosławieństwa, pokój i miłość Bożą”7. Wskazał na zasługi Kościoła w zakresie rozwijania i utrwalania więzi narodowej, co wynikało w dużej mierze z jednoczącego charakteru chrztu. Uogólniając swoją analizę i wnioski z tych rozważań, Autorka

\footnotetext{
${ }^{5}$ Wniosek ten Autorka przywołała za ks. Leszkiem Kucem. Patrz s. 37 recenzowanej publikacji.

6 Tamże, 49.

7 Tamże, 50.
} 
zauważyła, że zdaniem S. Wyszyńskiego bez Chrystusa i Jego Matki Maryi nie ma gwarancji prawdziwego postępu oraz bytu narodowego. W swoim nauczaniu milenijnym o narodzie Prymas zakotwiczał go w historii zbawienia, jako cząstkę Ludu Bożego, dzięki czemu naród był powołany do nieskończoności. Kończąc ten wątek, A. Rynio przeszła płynnie do części drugiej rozdziału zawierającej prezentację chrześcijańskiej pedagogii narodowej według S. Wyszyńskiego. Jej wizja zakładała następujące kierunki pedagogizacji narodu przez Kościół: dążenie do moralnego odrodzenia narodu, rozwijanie jego kultury duchowej, wspomaganie jego życia ekonomicznego i politycznego oraz wprowadzenie do rodziny narodów europejskich. Istotne w niej było również, że naród jest nie tylko przedmiotem pedagogizacji, ale i podmiotem wychowującym.

Kolejnym wątkiem, na jaki A. Rynio rzuciła światło, w pedagogii narodowej Prymasa Tysiąclecia jest wychowawcza funkcja historii. Autor kazań millenijnych dążył, aby w odniesieniu do niej wychowywać młodzież w duchu odpowiedzialności za dobro narodu. Dlatego samo przedstawianie historii przez tego duchownego opierało się na pokazywaniu konkretnych korzyści wynikających z rozwiązywania trudnych kwestii z przeszłości oraz argumentowania na rzecz wyboru dobra, w myśl pochodzącej od Cycerona antycznej maksymy historia magistra vitae est. Dla S. Wyszyńskiego historia miała budzić świadomość narodowej tożsamości. Z kolei w relacji do młodzieży to właśnie naród poprzez swoje dzieje miał być podmiotem wychowującym, inspirując ją ku dobru i słuszności.

Analizując odwołania do wydarzeń historycznych w prymasowskich kazaniach milenijnych, A. Rynio uszeregowała je według pewnego porządku. Ze zrozumiałych względów, zarówno z uwagi na doniosłość dziejową tego faktu, jak i jego szczególny wymiar w kontekście obchodów sacrum millenium, najważniejszym i najczęściej interpretowanym przez przepowiadającego był chrzest Polski. W dalszej kolejności były to wielkie zwycięstwa i klęski oręża, utrata niepodległości, powstania narodowe i udział w walkach narodowowyzwoleńczych, obozy zagłady itp. Cała historia narodu jest bowiem, według wizji S. Wyszyńskiego, na podobieństwo losów człowieka, historią zwycięstw i klęsk, a wszystkie one są pełną prawdą o niej, zaś wyciągane wnioski stanowią prawa rozwoju dziejów. Ksiądz Prymas przestrzegał również przed powtarzaniem błędów minionych pokoleń. Wspominał wybitne postacie historyczne, osoby świeckie i duchowne, będące kwintesencją chrześcijańskich dziejów narodu i Kościoła. Sposób, w jaki S. Wyszyński posługiwał się w swoim nauczaniu tym panteonem bohaterów narodowych oraz świętych i błogosławionych, czerpiąc z niego wzorce postępowania i osobowe dla młodych ludzi, omówiła Autorka we fragmencie rozdziału drugiego, zatytułowanym Potrzeba nowych świętych i błogosławionych. Jak zauważyła, praktycznie w każdym przypadku Kardynał uwypuklał fakt, iż ludzie wielcy powstawali w okolicznościach życiowej codzienności. Ich wzory dostarczały przykładów, „jak można przezwyciężać czasy i siebie, broniąc 
się przed samym sobą rzetelną pracą i modlitwą do Boga, który swoją mocą może wybronić nas z niewoli samych siebie".

W trzecim rozdziale poprzez analizę materiału źródłowego A. Rynio wyodrębniła i opisała elementy konstytutywne polskiej kultury narodowej. Należy zaznaczyć, iż dla przepowiadającego kultura polska była przede wszystkim kulturą chrześcijańską, tworzoną przez Kościół i naród ochrzczony, będący tym samym wspólnotą religijną, konsekwencją czego to właśnie wiara stawała się pierwszym spośród elementów konstytutywnych polskiej kultury narodowej. Przy czym głosząc prymat ducha nad materią, S. Wyszyński nie negował osiągnięć materialnych, postulował jednak, aby postrzegano je przede wszystkim jako oparcie dla duchowej kultury narodu. Ukazywał także fakt, iż w chrześcijańskiej rodzinie narodów to właśnie Polska, jako jedna z nielicznych, dochowała wierności Bogu. Stąd częste przywoływanie dewizy Polonia semper fidelis. Wspomniane dochowanie wierności Bogu to dochowanie wierności Chrystusowi. Z kolei jednym z wyrazów wierności wobec Chrystusa była wierność Jego Matce, uznanej w kazaniach milenijnych za główną Patronkę Narodu. W wierze ks. Prymas widział też źródło jedności Polaków oraz najbardziej znamienną cechę naszej kultury.

Drugim elementem charakterystycznym dla kultury polskiej według S. Wyszyńskiego, wyodrębnionym przez A. Rynio, jest umiłowanie wolności, rozumianej jako: prawa osoby, niepodległość narodowa, prawo narodu do samodzielnej egzystencji na danym terytorium, a także w sensie wolności od grzechu. Wszystko to, co zaprzecza wolnościom składającym się na prawa osoby ludzkiej, S. Wyszyński nazywał antykulturą.

W wolności osobistej, której źródłem jest Bóg, Prymas dostrzegał źródło wolności narodu, a w posiadaniu konkretnych wolności przez naród (religijnej, obywatelskiej, narodowej), warunek jego egzystencji. Stefan Wyszyński utożsamiał wolność narodu z wolnością Kościoła, a ta z kolei przejawia się w wolnościach do: głoszenia Ewangelii, katolickiego wychowania, działania w duchu Chrystusowym, miłowania słowem i czynem i oddawania czci Bogu. Na tym gruncie utożsamienia wolności narodowej z religijną jeszcze bardziej logiczny w wymiarze troski, zarówno o dobro Polaków, jak i Kościoła, stawał się akt milenijnego oddania się narodu polskiego w macierzyńską niewolę Maryi za wolność Kościoła w Polsce i w świecie współczesnym.

W omawianych poglądach S. Wyszyńskiego Autorka zauważyła jeszcze dwie kwestie. Pierwszą jest postrzeganie przez Prymasa umiłowania wolności jako jednej z charakterystycznych cech polskiej psychiki. Drugą kwestią jest natomiast wynikająca $z$ tej cechy konstytutywnej narodu głęboka tolerancja, co też przepowiadający udowadniał, przywołując w swoich kazaniach liczne, zaczerpnięte z historii przykłady, takie jak np. działalność Pawła Włodkowica na Soborze w Konstancji, Colloquium charitativum w Toruniu w 1645 roku czy brak wojen religijnych.

\footnotetext{
8 Tamże, 56.
} 
Strzeżenie depozytu wolności to według S. Wyszyńskiego dziejowa powinność Polaków. Jednocześnie ostrzegał on, iż konsekwencją utraty wolności duchowej jest utrata wolności politycznej.

Trzecią cechą polskiej kultury narodowej w omawianym wywodzie jest szacunek dla godności człowieka. Jest to też jedna z cech konstytutywnych kultury chrześcijańskiej, a jak zauważyła A. Rynio, fakt, że ks. Prymas poświęcał jej w swoich kazaniach dużo uwagi, wynikał z nauki Soboru Watykańskiego II, który w swoich dokumentach szeroko rozwinął to zagadnienie, zwłaszcza w Konstytucji duszpasterskiej o Kościele wświecie wspótczesnym. Uroczystości millenijne stanowiły dla Prymasa dogodną okazję do zapoznania społeczeństwa polskiego $\mathrm{z}$ rezultatami niedawnych obrad soborowych. Ponadto Autorka dowiodła również, że w rozważaniach na temat szacunku dla godności ludzkiej S. Wyszyński odwoływał się bezpośrednio do nauki ewangelicznej, encykliki O pokoju między wszystkimi narodami opartym na prawdzie, sprawiedliwości, miłości i wolności Jana XXIII i Powszechnej deklaracji praw człowieka ONZ. W godności osobowej Kardynał upatrywał źródło osobowych praw i obowiązków człowieka. Za podstawowe prawa osoby ludzkiej uznał: prawo do szacunku, wolności, sprawiedliwości, prawdy, miłości oraz pokoju. Jako konieczne wskazał uświadamianie sobie podstawowych praw i obowiązków ludzkich, jak również ich obronę. W opinii Autorki to właśnie kwestia ukazania godności osoby ludzkiej oraz jej podstawowych praw i obowiązków, a także ich świadomość stanowiła jeden z naczelnych celów kazań milenijnych.

W kolejnym podrozdziale został omówiony czwarty element konstytutywny polskiej kultury narodowej wyłaniający się z nauczania millenijnego S. Wyszyńskiego, jakim jest miłość do ojczyzny. Alina Rynio, analizując kazania, zauważyła, iż Prymas był głęboko przekonany, że jest ona cechą charakterystyczną Polaków. Jednocześnie widział w niej jeden z podstawowych obowiązków jednostki wobec narodu, stąd wielokrotnie starał się uświadamiać wiernym, jak należy dobrze spełniać tę powinność, wskazując przy tym na przykład Chrystusa. Szukając podstaw polskiego patriotyzmu w nauce objawionej, jednocześnie podkreślał jego historyczne tradycje. Zwracał też uwagę, iż miłość do ojczyzny winna się przejawiać poprzez szacunek do wszystkiego co ją stanowi, do jej przeszłości, teraźniejszości i przyszłości.

Przedmiotem analiz Autorki w czwartym rozdziale jej pracy jest odpowiedzialność za naród wynikająca z kazań milenijnych. Całość treści została tutaj podzielona na cztery podrozdziały, zawierające omówienie podstawowych obowiązków wobec narodu, sprecyzowanych i uzasadnionych przez S. Wyszyńskiego. Pierwszym z nich jest obowiązek wychowania człowieka do wszechstronnego rozwoju jego osobowości (podrozdział Wychowanie człowieka, obywatela i świętego). Alina Rynio wyjaśnia, iż według Prymasa ma ono być wychowaniem do odpowiedzialnego życia wiarą, dlatego też odpowiedzialność za naród została przez niego sprowadzona do odpowiedzialności za wiarę. Przepowiadający w przyjęciu i przekazywaniu wiary widział moc trwania narodu, stąd dochowanie wierności wierze ojców i strzeżenie jej depozytu uważał za zasadniczy wymiar dziejowej misji narodu. Stefan Wyszyński wskazywał na dużą rolę wychowawczą wzoru pozostawionego przez Chrystusa, 
Maryjęi Świętych. Tę funkcję pełnią także dzieje narodu, w tym w sposób szczególny ludzie, którzy na przestrzeni poszczególnych epok realizowali ewangeliczną świętość. Takie wzorce są niezbędne każdemu człowiekowi, rodzinie, narodowi i państwu. W tym kontekście ks. Prymas odwoływał się w swoich kazaniach między innymi do postaci św. Stanisława, Jadwigi Trzebnickiej, Jadwigi Wawelskiej, ale mówił też o Pawle Włodkowicu, jak również o „lekcjach” wynikających z konkretnych wydarzeń, takich jak zwycięstwa i klęski na polach bitew oraz inne zmagania narodu. Jak tłumaczy A. Rynio, S. Wyszyński w tych wydarzeniach i postaciach historycznych uwypuklał to, co było w nich pozytywnego, głównie wartości duchowe budujące życie. Ponadto ukazywał konieczność wychowania w wierności wobec ojczystej kultury. Jako obowiązki wobec narodu wynikające $\mathrm{z}$ tego postulatu wymienił: uczciwy przekaz młodemu pokoleniu tego, co stanowi kulturę, obronę rodzimej kultury, tworzenie nowych wartości kulturalnych w czasach obecnych. Stefan Wyszyński żądał dobrej znajomości i rozumienia historii ojczystej. Odpowiedzialność za wychowanie młodych pokoleń widział jako zadanie rodziców, Kościoła i państwa.

Drugim obowiązkiem związanym z odpowiedzialnością za naród jest konieczność zachowania zasad ewangelicznych w życiu społecznym. Pierwszą z nich w nauczaniu Prymasa Tysiąclecia jest zasada miłości. Analizując kazania szlaku milenijnego, A. Rynio zauważyła, iż ich twórca wyznacza dwa wymiary misji narodu polskiego. Pierwszy to poszerzanie i pogłębianie granic miłości do Boga i do ludzi, zaś drugi polega na dawaniu świadectwa światu w zakresie realizowania przykazania miłości Boga i bliźniego.

Jak twierdził Kardynał, uobecniając Boga przez miłość, Polska wciąż stanowić będzie dla cywilizacji zachodniej „bastion wiary” i „chrześcijańską przednią straż”. Miłość winna regulować osobiste stosunki z Bogiem, w rodzinie, narodzie, państwie oraz we wszelkich przejawach życia społecznego, publicznego, gospodarczego i międzynarodowego. Na gruncie miłości społecznej, budującej nowy ład Boży w pokoju, objawia się postulat sprawiedliwości jako kolejnej ewangelicznej zasady życia społecznego.

W dalszej kolejności A. Rynio pisze o trosce o życie narodu, którą S. Wyszyński uważał za jeden z podstawowych obowiązków wobec wspólnoty narodowej. Zagadnienie to ściśle skonkretyzował poprzez postawienie znaku równości pomiędzy życiem narodu a życiem dziecka, w tym nienarodzonego. Dostrzegał w postawie obrony zagrożonego życia konsekwencję wiary, uświadamiając wiernym, że niszczenie życia doprowadzi naród do zagłady. Kardynał sprzeciwiał się przyjętej w 1956 roku ustawie o przerywaniu ciąży, pozwalającej matce w praktyce w pełni decydować o dokonaniu aborcji dziecka9 ${ }^{9}$. Jako następne pole odpowiedzialności za naród

\footnotetext{
${ }^{9}$ Ustawa z 27 IV 1956 roku o warunkach dopuszczalności przerywania ciąży. Dz.U. 1956, nr 12, poz. 61. Ustawa wymieniała trzy okoliczności, w których dopuszczalne było dokonanie przez lekarza aborcji. Jedną $\mathrm{z}$ nich stanowiły trudne warunki życiowe kobiety będącej w ciąży, ustalane zgodnie z rozporządzeniem ministra zdrowia, jedynie na podstawie jej pisemnego oświadczenia.
} 
wskazywał rodzinę. W obronie rodziny widział podstawy dla egzystencji narodu, a byt narodu i państwa uzależniał od bytu rodziny. Stefan Wyszyński wzywał też do ducha ofiary i wyrzeczenia, niezbędnych do osiągnięcia pełni odpowiedzialności za naród, inspirował do pokonywania samolubstwa, egoizmu i wygodnictwa, propagował przemianę i odpowiedzialne życie wiarą.

W trzecim podrozdziale rozważań o odpowiedzialności za naród w prymasowskim nauczaniu milenijnym Autorka podjęła się pogłębienia zagadnienia wychowawczej roli dziejów ojczystych i kultury narodowej we wszystkich jej przejawach i formach. Kwintesencją stanowiska Kardynała w tym wymiarze było stwierdzenie, że z przeszłości trzeba wyciągać naukę dla teraźniejszości, mając nadzieję, iż naród wychowany na podstawie doświadczeń historycznych będzie w stanie zapewnić ojczyźnie właściwy rozwój duchowy, moralny, społeczny i ekonomiczny. $Z$ wychowawczą rolą dziejów narodowych wiązał konieczność ich poznania i zrozumienia. Ponadto według przepowiadającego z chrześcijańskiej przeszłości narodu należało przejąć wartości niezniszczalne - priorytetowe, takie jak miłość chrześcijańska, moralność ewangeliczna oraz dogmaty Kościoła. Stefan Wyszyński przeciwstawiał się też nieracjonalnemu wybrzydzaniu i krytykowaniu własnej historii, które w połączeniu z planową ateizacją i laicyzacją młodego pokolenia prowadziły do odchodzenia od kultury historycznej, twórczej i literackiej. Prymas stawiał przed młodymi szczytne cele i wymagania, głosił konieczność godnego życia, troski o społeczeństwo, domagał się pamięci o tych, którzy oddali życie za ojczyznę. Tę ostatnią uważał za nakaz wdzięczności i sprawiedliwości, jakie winny się przejawiać w oddawaniu czci spoczywającym na licznych cmentarzach obrońcom ojczyzny. Uważał to za ważny element kultury narodu. W sferze moralnej nawoływał do kierowania się ewangeliczną zasadą o miłości do nieprzyjaciół, którą przedstawiał młodym ludziom jako fundament chrześcijańskiej historii oraz tradycji patriotycznej. Uważał, iż naród polski, jako że ma wpisany w swój dorobek doświadczenie krzyża Chrystusa, nie może nie wychowywać w duchu wierności wiekowemu dziedzictwu, aczkolwiek każda generacja wnosi nowe wartości do rozwoju rodziny ludzkiej.

Obszerny fragment recenzowanej pracy stanowi podrozdział pt. Rola małżeństwa i rodziny w odpowiedzialnym wychowaniu dzieci i młodzieży. Według A. Rynio to właśnie małżeństwo i rodzina stoją w centrum prymasowskiego nauczania. Jako cele małżeństwa Kardynał wskazał wspólność życia, prokreację i wychowanie potomstwa, zaś jako zadania rodziny wymienił: zachowanie jedności serc i pokój rodzinny, udzielanie życia dzieciom i wychowanie ich, przekazanie tradycji rodzinnych, opiekę nad rodzicami na starość, kształtowanie charakterów, wzmacnianie sił żywotnych i potęgowanie możliwości rozwoju oraz postępu narodu. Z tymi zadaniami powiązane są obowiązki, jakie rodzina ma do spełnienia, wyodrębnione i omówione przez Autorkę (przywołującej w tym aspekcie badania Magdaleny Parzyszek). Są to: żyć w miłości i pokoju, dać życie, przygotować dzieci do zadań społecznych i obywatelskich, dać szkołę pracy i oszczędności. Z zagadnieniem pracy S. Wyszyński powiązał bezpośrednio konieczność kształtowania cnót, do których 
zaliczył: cierpliwość, długomyślność (możliwość zdobycia ducha długotrwałego dążenia do odległych dóbr), wytrwałość, cichość i sumienność.

Analizująca prymasowskie nauczanie na temat małżeństwa i rodziny A. Rynio zauważyła, iż ks. Kardynał rzeczywistość z nimi związaną widział w wielu wymiarach - społecznym (rodzina jako bastion wiary i polskości), psycho-pedagogicznym i kulturowym oraz sakramentalnym i eklezjalnym (wspólnota Kościoła domowego). Dostrzegał zagrożenia dla rodziny i będące ich skutkami kryzysy. Wśród nich wskazywał: indoktrynację komunistyczną, programowe niszczenie więzi międzyludzkich, antagonizowanie pokoleń, podważanie szacunku dla ludzkiego życia. Często poruszał kwestię trudnych warunków socjalnych polskich rodzin, wpływających destrukcyjnie na ich kondycję psychofizyczną. Kreślił przy tym konkretny program poprawy funkcjonowania wspólnoty rodzinnej, kładąc w nim nacisk na rodziny wielodzietne, postulując poszerzenie ich praw obywatelskich. Zwracał uwagę na zaniedbanie i lekceważenie wartości życia małżeńskiego i rodzinnego. Piętnował patologie i naganne praktyki społeczne, uderzające w życie małżeńskie i rodzinne, stojące w sprzeczności z moralnością chrześcijańską (pijaństwo, rozwiązłość, degeneracja zachowań młodzieży, ateizm - „rak duszy”, upadek kultury życia codziennego, masowa aborcja traktowana jako rodzaj antykoncepcji). Przeciwstawiał temu podniesienie społecznej rangi małżeństwa poprzez nadanie mu charakteru sakralnego oraz wskazując, iż jest ono zarówno instytucją, jak i powołaniem. Oprócz licznych zagrożeń zewnętrznych dezintegrujących rodzinę, nazywa wprost również zagrożenia wewnętrzne. Są to: zdrady, panseksualizm, narkomania, egoizm, samolubstwo, moralność antykoncepcyjna, lenistwo, lekkomyślność, marnotrawienie dóbr materialnych, brak ducha ofiary, indywidualizm, niedbałość, wygodnictwo, rozrzutność, powierzchowność. Na tle analizowanego prymasowskiego nauczania Autorka postawiła znamienną tezę, stwierdzając, iż jego nauczanie dotyczące rodziny odbiega od promowanego obecnie w przestrzeni publicznej modelu łatwego i przyjemnego życia. Alina Rynio słusznie też podkreśliła, że w aktualnej rzeczywistości, w której dokonuje się reorganizacja rozumienia małżeństwa i rodziny, zmieniające się warunki społeczno-ekonomiczne i cywilizacyjno-kulturowe domagają się działań mających na celu lepsze przygotowanie młodych ludzi do ról małżeńskich i rodzinnych. W tym kontekście pomocą w tych działaniach powinna być między innymi popularyzacja nauczania Prymasa Tysiąclecia.

Stefan Wyszyński uznawał dziecko za najważniejszą wartość w małżeństwie i centralny ośrodek życia rodzinnego. W swojej koncepcji wychowania ten wybitny duchowny poprzez ukazanie siły rodzimej tradycji obojga rodziców zobowiązywał ich do wychowania społecznego, religijnego i moralnego swoich dzieci. Tłumaczył, iż rodzice wychowują nie tylko za pomocą przemyślanych i świadomych zabiegów pedagogicznych, ale i poprzez styl wzajemnego odnoszenia się do siebie i innych, a także poprzez atmosferę i klimat życia rodzinnego. Z kolei źródło prymatu wychowawczego rodziny wskazywał w potrójnej misji Chrystusa: prorockiej, kapłańskiej i królewskiej. 
W tej kompleksowej koncepcji wychowania S. Wyszyńskiego, jak dowodzi A. Rynio, szczególne miejsce przypada wychowaniu religijnemu i moralnemu. Prymas Polski był przekonany, że religijność rodziców zostawia niezatarty ślad w psychice dziecka. Domagał się od rodziców rzetelnej pobożności na co dzień, wrażliwości i otwartości na problemy współczesności. Postulował równoczesne rozwijanie walorów religijnych i osobistych przez kształcenie rozumu i woli wychowanków, tak aby osiągnęli pełnię rozwoju osobowego.

Alina Rynio zwróciła uwagę, iż S. Wyszyński wyprowadzał obowiązki wychowawcze małżonków względem dzieci z sakramentalności małżeństwa, na mocy której rodzice traktujący dzieci jako dar Boga otrzymują od Kościoła kanoniczne posłannictwo do nauczania dzieci prawd wiary katolickiej. Odpowiedzialność za wypełnienie tego posłannictwa ponoszą przez Bogiem, Kościołem, narodem i swoimi dziećmi.

Całokształt myśli i koncepcji wychowawczej Kardynała to, jak podsumowała A. Rynio, wychowanie oparte na rozumności, miłości, wiedzy, doświadczeniu, mądrości, wierze i religii, gwarantujące realny, integralny rozwój człowieka. Koncepcja ta jest oparta na poznaniu ludzkiej natury u progu rozwoju i stworzeniu możliwie najlepszych warunków do dalszego jej wzrastania. Stefan Wyszyński uświadamiał też, iż rodzina nie stanowi jedynej grupy posiadającej depozyt ideałów, wartości i wzorców zachowań. Rodzice mogą czerpać je z grup szerszych, takich jak Kościół i naród. Dlatego to przed rodziną stoi zadanie ratowania bytu narodowego i rodzimej kultury chrześcijańskiej. Stąd wspólnemu, rodzinnemu obchodzeniu świąt, rocznic religijnych, rodzinnych i państwowych ks. Prymas przypisywał duże znaczenie pedagogiczne.

Ostatni rozdział merytoryczny swojej pracy A. Rynio zatytułowała wymownie Argumenty przemawiajace za potrzebą znajomości prymasowskiego rozumienia idei narodu i odpowiedzialności za naród. Dokonując omówienia wspomnianej (wybranej) argumentacji, jego podstawą uczyniła badania własne, zawarte we wcześniejszych rozdziałach recenzowanego opracowania, badania własne publikowane wcześniej i wychodzące zakresem rozważań poza kazania milenijne, jak również analizy innych autorów (między innymi ks. Stanisława Kowalczyka, Jerzego Lewandowskiego, ks. Czesława Bartnika, Ziemowita Gawskiego).

W pierwszym podrozdziale dokonała namysłu nad ponadczasową wartością idei narodu i odpowiedzialności za naród Kardynała S. Wyszyńskiego. Zaznaczyła, iż idea narodu wyłaniająca się z poglądów społecznych Prymasa opiera się nie tylko na rzeczywistości polskiej, ale też na jego uczuciach osobistych, głębokiej miłości do własnego narodu, poglądach etycznych oraz filozoficzno-społecznych. Kształtowała się na przestrzeni lat i była wyrażana w szeregu jego prac i wypowiedzi. Stefan Wyszyński wypracował zarys personalizmu narodowego, dopełniony personalizmem chrześcijańskim.

W dalszej kolejności A. Rynio omówiła stanowisko S. Wyszyńskiego w takich kwestiach jak: znaczenie posiadania własnego terytorium; respektowanie 
praw narodu; historia i kultura jako podstawowe elementy podmiotowe narodu; społeczno-wspólnotowy personalizm ks. Kardynała oraz fundamentalne zasady życia społecznego (personalizm, dobro wspólne, solidarność), miłość do własnego kraju (patriotyzm) oraz posłannictwo narodu względem innych wspólnot narodowych. To ostanie zagadnienie S. Wyszyński łączył z kwestią praw narodów, sprawiedliwości i ładu międzynarodowego. Posiłkując się badaniami ks. Cz. Bartnika, Autorka wyodrębniła zbiór 12 praw narodu, wyłaniających się z prymasowskiego nauczania. W tym kontekście wyjaśniła również bezpodstawność zarzutów o religijny nacjonalizm (rzekome postulowanie powrotu do XVI-wiecznej koncepcji Kościołów narodowych) formułowanych niekiedy wobec idei narodu ks. Kardynała, nadającego mu kategorię eklezjologiczną, według której Kościół chrześcijański miał się ucieleśniać wielokrotnie w takich podmiotach jak: rodzina, parafia, diecezja, naród czy też w Międzynarodowej Rodzinie Narodów.

Znaczny fragment tego podrozdziału poświęcony został przedłożeniu argumentacji związanej z podkreśleniem znaczenia prymasowskiego postulatu uznania dziejów narodu za niezastąpiony czynnik wychowawczy młodych pokoleń Polaków. Ciekawą tezą Autorki jest spostrzeżenie, że ideał wychowania młodzieży S. Wyszyńskiego ma dużo punktów zbieżnych $\mathrm{z}$ ideałem sprecyzowanym $\mathrm{w}$ systemie prewencyjnym św. Jana Bosko, jak również ideałami sformułowanymi przez: Roberta Baden-Powella, ojca Jacka Woronieckiego, bł. Edmunda Bojanowskiego, bł. Bronisława Markiewicza, bł. Marcelinę Darowską, św. Urszulę Ledóchowską, a nawet młodzież z batalionu „Zośka” oraz szerzej, Armii Krajowej, i dalej wszystkich tych, którzy walczyli w narodowych insurekcjach o wolność naszej ojczyzny i innych nacji. Następnie Autorka udzieliła obszernej odpowiedzi na postawione przez siebie pytanie dotyczące najistotniejszego celu wychowania dzieci i młodzieży według ks. Kardynała. Ważną konstatacją w tym aspekcie jest uwaga, że S. Wyszyński wyróżnił wychowanie człowieka, obywatela i świętego, a odpowiadające tym płaszczyznom cele wynikały z przyjmowanych przez niego założeń antropologicznych, społecznych i teologicznych. Zostały one omówione przez A. Rynio w następnych passusach tej części opracowania. W konkluzji tych rozważań podkreśliła ona, iż cała narodowa pedagogia ks. Kardynała bez wątpienia zasługuje na miano pedagogiki integralnej. Umożliwia ona człowiekowi podążanie ku pełni wolności drogą uczestnictwa w prawdach chrześcijańskiego orędzia zbawienia. Droga ta nabiera szczególnego znaczenia na tle współczesnego materialistycznego redukowania ludzkiej egzystencji wyłącznie do roli anonimowego obywatela ludzkiego państwa. W wyniku swoich analiz A. Rynio dowiodła też, iż S. Wyszyński bronił prawa do wszechstronnego wychowania oraz trafnie przekonywał o historycznej pożyteczności obecności świadomych chrześcijan w świecie.

Drugi podrozdział to syntetyczne przedstawienie argumentacji przemawiającej za oryginalnością i znaczeniem analizowanej myśli Prymasa Tysiąclecia. Autorka zawarła w nim spostrzeżenie, iż owoce wszechstronnego naukowego namysłu nad kazaniami milenijnymi mają charakter uniwersalny i ponadczasowy, a poprzez to 
winny znaleźć zastosowanie praktyczne w procesie dydaktyczno-pedagogicznych oddziaływań na dzieci, młodzież oraz społeczności wychowujące. Stefan Wyszyński, mimo że był wysoko postawionym w hierarchii Kościoła duchownym, potrafił patrzeć na świat ludzi młodych $\mathrm{z}$ ich perspektywy, nie ograniczał się wyłącznie do roli osoby pouczającej i autorytarnie narzucającej gotowe rozwiązania. Alina Rynio podkreśliła, że prymasowska pedagogia narodowa jest pedagogią wiary, nadziei i miłości i choć nie można jej do końca uznać za pełną teorię naukową, to w praktycznym wymiarze jest istotnym kierunkiem wychowawczym dla człowieka wierzącego. Ksiądz Kardynał ukazywał proces wychowania jako współdziałanie wychowanka i wychowawcy z łaską Bożą, w którym można uniknąć dwutorowości polegającej na oddzieleniu myślenia i działania religijnego od życia zawodowego i społecznego. Stefan Wyszyński postuluje permanentną weryfikację prawd i wymagań Bożych poprzez odniesienie ich do aktualnej rzeczywistości, w której żyjemy i funkcjonujemy. Ten aspekt prymasowskiego nauczania Autorka uznała za dowód jego realizmu pedagogicznego. Dowiodła też, że S. Wyszyński w swoim nauczaniu połączył filozofię wychowania z elementami metafizycznymi, co miało inspirujący wpływ na dyskusje próbujące określić części składowe zarówno treści wychowania młodzieży, jak też ich wyborów i postaw.

W wieńczącym całą rozprawę zakończeniu Autorka dokonała właściwych tej części opracowania podsumowań, konkluzji i wniosków oraz przedstawiła postulaty badawcze, wśród których za priorytetowy należy uznać konieczność badań nad zagadnieniem aktualności koncepcji narodu zawartej w całokształcie dorobku publikacji naukowych i kaznodziejskich ks. Kardynała.

W podsumowaniu trzeba $\mathrm{z}$ całą pewnością stwierdzić, iż recenzowana publikacja jest dziełem niezwykle wartościowym i potrzebnym. Nie ulega wątpliwości, iż A. Rynio udało się osiągnąć zamierzony cel badawczy, jakim była próba ukazania idei narodu i odpowiedzialności za naród zawartej w kazaniach millenijnych Kardynała S. Wyszyńskiego. Jak sama Autorka wielokrotnie podkreślała na kartach swojej książki, namysł pedagogiczny nad nauczaniem Prymasa towarzyszył jej praktycznie od początku działalności naukowej, o czym świadczy fakt, że bazą dla omawianego opracowania była jej praca magisterska, obroniona w 1979 roku, czyli jeszcze za życia S. Wyszyńskiego, a tuż przed powstaniem NSZZ „Solidarność” oraz na dziesięć lat przed upadkiem komunizmu i początkiem transformacji ustrojowo-gospodarczej w Polsce. W ciągu kolejnych czterech dekad A. Rynio niezmiennie zajmowała się problematyką nauczania $S$. Wyszyńskiego, stając się jednym z najważniejszych autorytetów naukowych w tej tematyce w Polsce. Mając tę perspektywę historyczną wraz ze świadomością jej konsekwencji społecznych oraz bogaty dorobek naukowy i szeroką erudycję nie tylko pedagogiczną, ale i z obszaru teologii i psychologii, zdecydowała się zaktualizować, rozszerzyć i pogłębić swoje dotychczasowe analizy i włączyć je do obecnego stanu badań nad osobą i dziedzictwem Prymasa Tysiąclecia poprzez publikację omawianej tutaj pracy. Wzmocnieniem zawartego w niej 
przekazu jest kontekst wciąż oczekiwanego finału procesu beatyfikacyjnego Sługi Bożego S. Wyszyńskiego, który początkowo był planowany na 7 czerwca 2020 roku.

Zagłębiając się w analizy A. Rynio, można stwierdzić bez najmniejszej wątpliwości, że udało się tej uczonej wykazać wielopłaszczyznowość idei narodu oraz koncepcji wychowania ks. Kardynała, a także udowodnić jej oryginalność i aktualne znaczenie w kontekście współczesnych uwarunkowań społecznych oraz wyzwań i sporów cywilizacyjnych. Jej praca, w opinii recenzującego, jest oczekiwaną odpowiedzią nie tylko na potrzebę popularyzacji osoby i myśli Kardynała, ale i (a może bardziej) na konieczność pogłębionej refleksji naukowej, mającej na celu zrozumienie i wyjaśnienie tego szczególnego dziedzictwa dla Kościoła, państwa i narodu polskiego, jakim jest prymasowska spuścizna kaznodziejska i jego nauczanie. Omawiana praca A. Rynio jest ważnym głosem w dyskursie naukowym, będącym jednoznacznym wystąpieniem w obronie nauczania S. Wyszyńskiego oraz wpisującym je do dziedzictwa humanistyki narodowej i polskiej myśli pedagogicznej. Oby nigdy, tak jak stwierdziła sama Autorka w jednym ze swoich artykułów blisko dziesięć lat temu, za rzetelne zajmowanie się osobą i nauczaniem S. Wyszyńskiego nikogo nie spotkała już „niezasłużona kara i ocena, »że temat dla nauki i mało naukowy i nie na czasie, bo Prymas taki Polski, taki autorytarny i tak mało europejski«"10.

\section{Bibliografia}

Rynio, Alina. „Mądre wychowanie patriotyczne przedmiotem troski Prymasa Tysiąclecia”. Studia Prymasowskie 5 (2011): 247-264.

Rynio, Alina. Idea narodu i odpowiedzialności za naród w kazaniach milenijnych Czcigodnego Stugi Bożego Kardynała Stefana Wyszyńskiego. Studium homiletyczno-pedagogiczne. Lublin: Wydawnictwo KUL, 2020.

Tuziak, Bożena. „Autorytet jako zjawisko społeczne. Wymiar lokalny”. Studia Socjologiczne 2 (2010): 53-88.

Ustawa z 27 kwietnia 1956 roku o warunkach dopuszczalności przerywania ciąży. Dz.U. 1956, nr 12, poz. 61.

Zieliński, Zygmunt. Kościół w kręgu rzeczywistości politycznej. Lublin: Wydawnictwo KUL, 2003.

Paweł Juśko ${ }^{11}$

Uniwersytet Rzeszowski

http://orcid.org/0000-0002-8474-604X

10 Zob. Alina Rynio, „Mądre wychowanie patriotyczne przedmiotem troski Prymasa Tysiąclecia”. Studia Prymasowskie 5 (2011): 247.

11 Dr Paweł Juśko - Uniwersytet Rzeszowski, Instytut Pedagogiki, Katedra Badań Szkoły. Adres do korespondencji: ul. ks. J. Jałowego 24,35-010 Rzeszów; e-mail: pjusko@ur.edu.pl. 